http://kitaibelia.unideb.hu/

ISSN 2064-4507 (Online) • ISSN 1219-9672 (Print)

(C) Department of Botany, University of Debrecen, Hungary

26(1): 3-9.; 2021

DOI: $10.17542 /$ kit.26.3

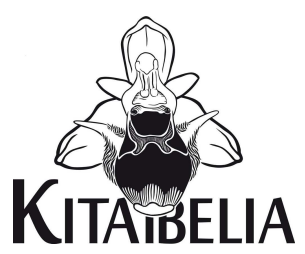

\title{
Egy ritka iszapnövény, a Spergularia echinosperma egykori előfordulása Magyarországon
}

\author{
Mesterházy Attila1* \& KúR Pavel² \\ (1) H-9500 Celldömölk, Hunyadi utca 55.; *amesterhazy@gmail.com \\ (2) University of Vienna, Department of Botany and Biodiversity Research, A-1030 Wien, Rennweg 14.
}

\section{Historical occurrence of Spergularia echinosperma, a rare Nanocyperion species in Hungary}

\begin{abstract}
Three species of the genus Spergularia have been known from Hungary. The most widespread one, Spergularia rubra (L.) J. Presl et C. Presl occurs on young sandy fallow fields and other disturbed habitats. The other species, S. marina (L.) Bess. and S. media (L.) C. Presl, occur sporadically in saline grasslands, and both have been recently spreading along salted roads. During a revision of the genus Spergularia in Hungarian herbaria, specimens of the species S. echinosperma (Čelak.) Asch. et Graebn. were found. It is a rare species previously known to occur only in Czechia and Germany and to be extinct in Austria and Slovakia (a few occurrences along the Morava and Danube rivers between 1909 and 1953). However, it was recently discovered in Western Siberia and Kazakhstan. It is a typical mudflat plant that occurs on exposed sandy shores of water bodies. Two herbarium sheets collected by Gyula Tauscher from near the village of Ercsi (riverbank of the Danube) in 1903 were found in the Carpato-Pannonicum collection of the Hungarian Natural History Museum. In addition, a new specimen was found, collected in Slovakia (Danube near Šamorín, collected by Mihály Résely in 1868) at the vicinity of the Hungarian border. The species was not confirmed during a field inspection of the target localities in Hungary; therefore, we have to consider it extinct in the country as well as in the whole Pannonian Basin. Recently, S. echinosperma was split into two subspecies - subsp. echinosperma and subsp. albensis. The subsp. echinosperma is probably restricted to fishponds in the SW part of Czechia and subsp. albensis occurs mainly in the floodplains of the river Elbe in Germany. The extinct populations of $S$. echinosperma in the Pannonian Basin belonged to the subsp. albensis. This taxon is morphologically close to $S$. rubra but can be reliably distinguished by densely verrucose seeds and shorter than wide stipules.
\end{abstract}

Keywords: ephemeral wetland vegetation, Hungarian flora, revision, Spergularia rubra

Összefoglalás - Magyarország területéről eddig 3 budavirág faj előfordulása volt ismert. A fiatal parlagokon, nyílt felszíneken élő Spergularia rubra (L.) J. Presl et C. Presl elterjedt faj, míg a szikeseken szórványosan előforduló $S$. marina (L.) Bess. és $S$. media (L.) C. Presl az utóbbi években magasabbrendű útjaink mellett terjedőben van. A budavirágfajok herbáriumi revíziója során a közép-európai elterjedésű S. echinosperma példányait találtuk meg a MTM Növénytára Carpato-Pannonicum gyüjteményében. A faj két lapját Tauscher Gyula gyűjtötte Ercsi mellett 1903-ban. További gyűjtés került elő a határ közvetlen közelében lévő szlovákiai Somorján. A gyűjtési helyek terepi ellenőrzése során a faj nem került elő, ezért jelenleg hazánkból kipusztultnak kell tekintenünk. Korábban a Kárpát-medencében Ausztriában és Szlovákiában is gyüjtötték, de ezeket az adatokat napjainkban szintén nem erősítették meg. A S. echinosperma hasonlít a $S$. rubra-hoz, de attól sűrűn bibircses magja és rövidebb pálhái alapján biztosan elkülöníthető. A hazai példányok a sötétbarna magvú subsp. albensis-hez tartoznak.

Kulcsszavak: iszapnövények, magyar flóra, revízió, Spergularia rubra 


\section{Bevezetés}

A kozmopolita Spergularia (Pers.) J. Presl et C. Presl nemzetség fajait mértékadó munkák (Friedrich 1979, DVoŘÁK 1990, BITTRICH 1993, HARTMAN \& RABElER 2005) 20 és 60 közé teszik. Az elfogadott fajok számának jelentős különbségéből látszik, hogy egy taxonómiailag még nem kellő mértékben tisztázott csoportról van szó. Az idetartozó, döntően sókedvelő (halofita) növények géncentrumai Dél-Amerikában és Európa mediterrán régiójában vannak (FRIEDRICH 1979, MONNIER \& RATTER 1993).

A nemzetségnek Közép-Európában öt faja fordul elő, ezek közül három ismert Magyarországon (Anon. 2009). A S. marina (L.) Bess. (syn.: S. salina J. Presl et C. Presl) és a S. media (L.) C. Presl (syn: S. maritima (All.) Chiov.) egyaránt rövid életű évelő növények, melyek leginkább alföldi szikeseink nyílt élőhelyein jelennek meg. Mindkét faj eredeti termőhelyein szórványosan fordul elő: a flóraatlasz (BARTHA et al. 2015) a $S$. marina-t mindössze 23, míg a $S$. media-t 36 flóratérképezési egységből jelzi. Az utóbbi évtizedben mindkét faj másodlagosan megjelent az utak mellett és napjainkban nagymértékű terjedésüknek lehetünk szemtanúi (SCHMidT et al. 2018). A hazánkban előforduló harmadik faj a S. rubra (L.) J. Presl et C. Presl, mely nedves, nyílt, tápanyagszegény felszíneken, egy-két éves parlagokon, valamint vetésszegélyekben viszonylag elterjedt fajnak számít.

A S. echinosperma (Čelak.) Asch. et Graebn.-t Európában endemikus fajnak tartják (FRIEDRICH 1979, DVOŘÁK 1990), bár észlelték már Észak-Afrikában (MonNIER 1968) és ÉszakAmerikában (HARTMAN \& RABELER 2005), de napjainkban előkerült Nyugat-Szibéria számos pontján (EBEL 2012, TARAN et al. 2018) és Kazahsztánból (EFREMOV et al. 2019) is. Az Európán kívüli állományoknak a taxonómiai helyzete, illetve a közép-európai populációkkal fennálló rokonsági viszonyuk azonban még nem kellően tisztázott (Kúr P. ined.).

A faj Európában ritka, mindössze Németországban és Csehországban ismertek jelentősebb előfordulásai. Németországban adatai főleg az Elba folyó árterületéhez kötődnek, míg Csehországban többnyire az ország déli és nyugati régióiban lévő halastavakban fordul elő (FriEDRICH 1979, DVOŘÁK 1990, KÚR et al. 2017).

A növény nem ismeretlen a Kárpát-medencében sem: Ausztriában és Szlovákiában is gyưjtötték korábban a Duna vízgyưjtőterületén. Ausztriában két adat ismert a Morva folyó mentéről, ezek 1902-ből és 1934-ből származnak (KúR et al. 2018). Szlovákiából szintén két adata származik a Morva folyó árteréről, továbbá Pozsony (Bratislava) környékén és a Vág mellett (Kolárovo) is megtalálták (DvoŘÁK 1979) (1. ábra). Mind a négy adat még az 1900-as évek első feléből származik, Szlovákiában a fajt kipusztultnak tartják (extinct) (ELIÁš et al. 2014). Ausztriában a Třeboňi-medencével érintkező területeken (Waldviertel) még ismert néhány recens adata, a fajt az országban kipusztulással veszélyeztetettként tartják nyilván (NikLFELD \& SCHRATT-EHRENDORFER 1999). Ugyancsak veszélyeztetettnek (endangered) minősül Csehországban (GRULICH 2012), míg Németország egyes tartományainak vörös könyvében is szerepel (Mecklenburg-Vorpommern: VoIGTLÄNDER \& HENKER 2005; SchleswigHolstein: Mierwald \& Romahn 2006; Hamburg: PopPENDiEcK et al. 2010; Sachsen: SchulZ 2013).

A taxont ČElaKovSKÝ (1881) a S. rubra alfajaként írta le, saját, Dél-csehországi (Protivín) gyűjtése alapján. A lektotípus kijelölését KúR et al. (2012) végezte el Čelakovský gyűjtésén. ASCHERSON \& GRAEBNER (1893) emelték faji rangra, azóta a legtöbb Spergularia taxonómiával foglalkozó összefoglaló munka ezt az álláspontot képviseli (FRIEDRICH 1979, MONNIER \& RATTER 1993). A S. echinosperma morfológiailag azonban olyan közel áll a S. rubra-hoz, hogy más szerzők (JAGE 1974, DvoŘÁK 1990) faji önállóságát továbbra is kétségbe vonták. A két taxon elkülönítésében további problémát okoz, hogy azok hibridizálódnak is egymással. A $S$. ×kurkae-t DvoŘÁK (1989) mint a két faj primer hibridjét írta le. Később dokumentálták a hibrid „visszakereszteződését” az egyik szülőfajjal, a S. rubra-val (KúR et al. 2016). 
A közelmúlt molekuláris genetikai és kariológiai munkái (KúR et al. 2012, 2016, 2017) megerősítették, hogy a $S$. ×kurkae valóban egy állandósult önbeporzó allotetraploid hibrid a diploid S. echinosperma és a tetraploid S. rubra között. Mivel az önmegtermékenyítés révén képes a reprodukcióra és stabil morfológiai bélyegekkel rendelkezik, KúR et al. (2016) $S$. kurkae néven (azaz a hibrid formula elhagyásával) a taxon teljes faji rangú használatát javasolják. Ez a taxon úgy tűnik, a $S$. echinosperma-nál jobban tűri az élőhelyek degradációját, mivel gyakran megjelenik olyan erősen bolygatott helyeken is, ahonnét az előbbi már eltűnt. Emiatt Csehországban a S. kurkae gyakoribbá vált a S. echinosperma-nál (KúR et al. 2018).

A S. echinosperma-nak nemrégiben egy subsp. albensis Kúr alfaját is leírták (KúR et al. 2017), mely a subsp. echinosperma-nál jóval elterjedtebb. A törzsalak úgy tűnik, csak DélCsehországban fordul elő, míg a subsp. albensis legtöbb aktuális adata Németországból származik (KúR et al. 2017).

A S. echinosperma élőhelyigényét tekintve egy tipikus egyéves életformájú iszapnövény, mely belvizekben, tavak parti zónájában, folyók homok- és iszappadjain, de gyakran halastavak kiszáradó medrében fordul elő. A meliorációnak, folyószabályozásoknak köszönhetően számos korábbi lelőhelyéről eltűnt, Európában veszélyeztetetté vált (DvoŘÁK 1990, KúR et al. 2018).

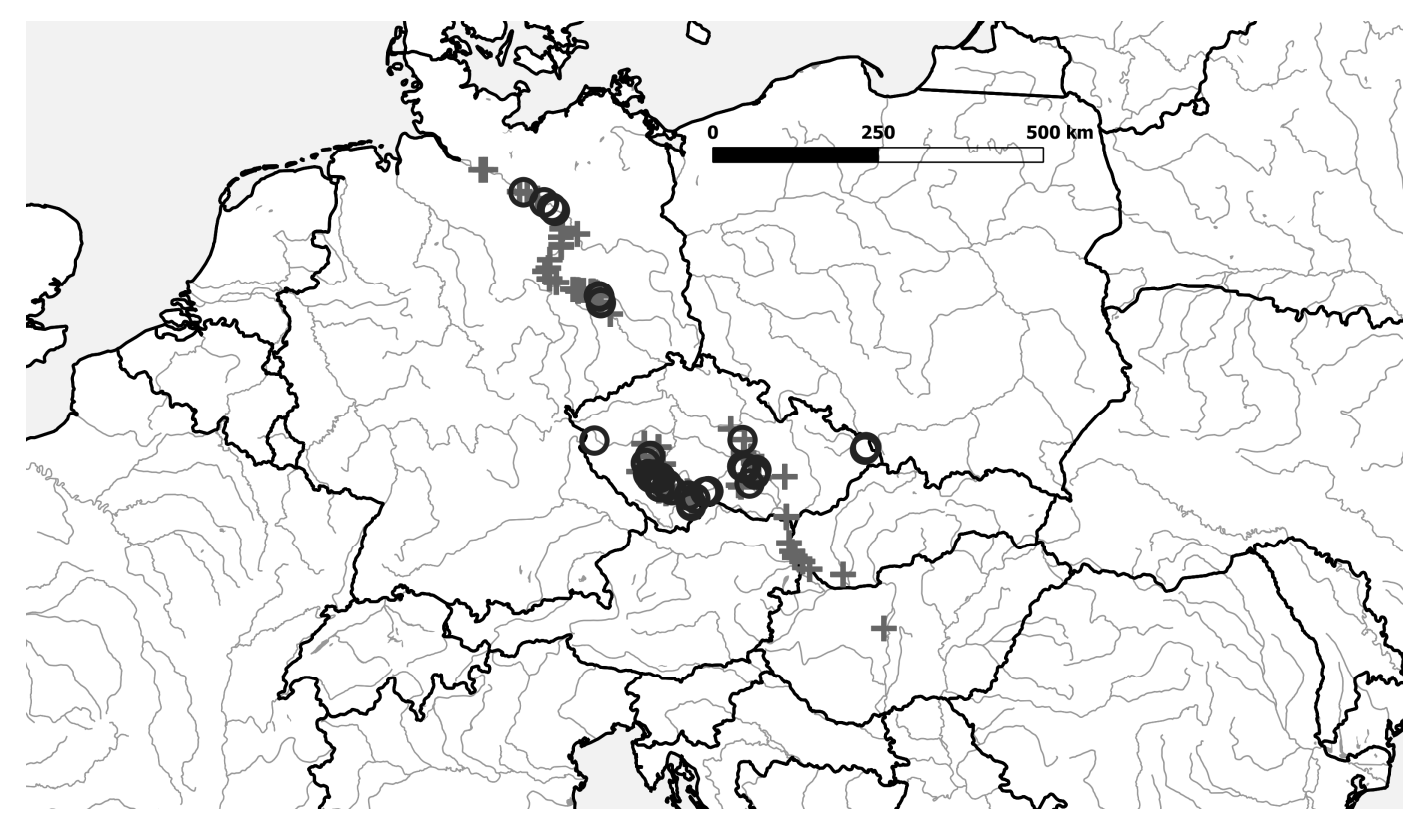

1. ábra A S. echinosperma európai elterjedése (eredeti) (O: recens adatok, +: 2000 előtti adatok)

Fig. 1 European distribution of $S$. echinosperma (original) (O: records after 2000, +: records before 2000)

\section{Anyag és módszer}

A budavirág fajok kárpát-medencei gyűjtéseit a Magyar Természettudományi Múzeum Növénytárának (BP) Carpato-Pannonicum gyüjteményében vizsgáltuk meg. A határozáshoz KúR et al. $(2012,2016)$ munkáit használtuk fel. A növények vizsgálatát sztereomikroszkóppal végeztük. A faj korábbi magyarországi lelőhelyén (Ercsi) és a Duna menti potenciális élőhelyeken (Szigetköz, Gemenc, Béda) a terepi kutatásokat 2018-2019 nyarán végeztük. 


\section{Eredmények}

A Spergularia fajok herbáriumi revíziója során a hazánkban korábban nem ismert S. echinosperma két példánya került elő, mindkettőt Tauscher Gyula gyűjtötte az 1800-as évek második felében. A példányokat a gyűjtő $S$. rubra-nak határozta. A teljes hazai Spergularia anyagot 1903-ban Julien Foucaud revideálta, és már ő is felismerte, hogy a szóban forgó példányok egy része a $S$. echinosperma-hoz tartozik. Azonban a BP 644426-as herbáriumi lapon a két $S$. echinosperma gyüjtés mellett egy $S$. rubra példány is található. Foucaud 1904-ben elhunyt, így az általa tervezett Spergularia monográfia a magyar adatokkal soha nem került publikálásra. Később a budavirág gyűjtéseket Felföldy Lajos revideálta, ő Tauscher szóban forgó lapjait mind $S$. rubra-nak határozta.

A szóban forgó növények magjai a sűrű bibircsességükben ütöttek el leginkább a $S$. rubratól (2. ábra), de a levelek pálhái is azokénál jóval kisebbek voltak (3. ábra). Ez alapján a növényeket $S$. echinosperma-nak határoztuk, megerősítve ezzel Foucaud határozását. A tipikus S. echinosperma magjai feketék, míg a hazai példányok magjai mind sötétbarnák voltak, tehát a közelmúltban leírt susbp. albensis-hez sorolhatók. A korábban Kárpát-medencében (Ausztria, Szlovákia) gyüjtött példányok is mind ehhez az alfajhoz tartoztak (KúR et al. 2018). A hasonlóan sűrün bibircses magvú $S$. kurkae pálhái a magyar példányokénál hosszabbak (11,7 × hosszabbak szélességüknél) valamint magjuk fekete.
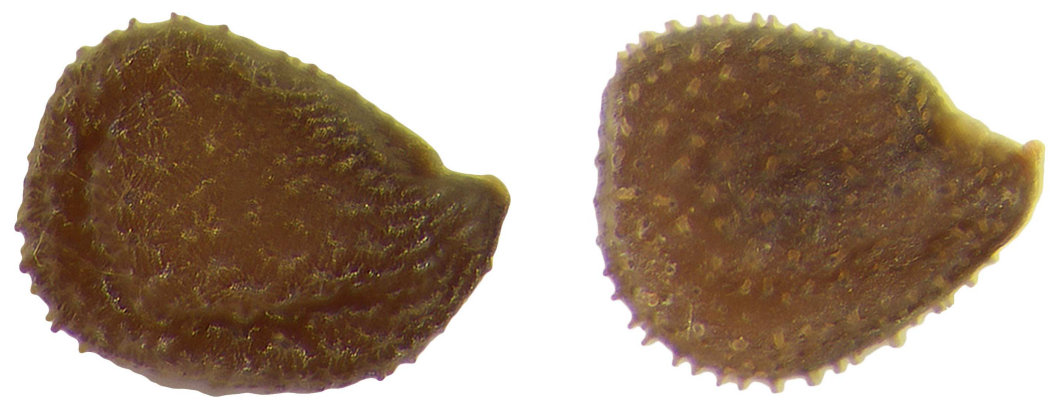

2. ábra A S. rubra (bal) és a S. echinosperma (jobb) magjai (KúR et al. 2017) Fig. 2 Seeds of S. rubra (left) and S. echinosperma (right) (KúR et al. 2017)
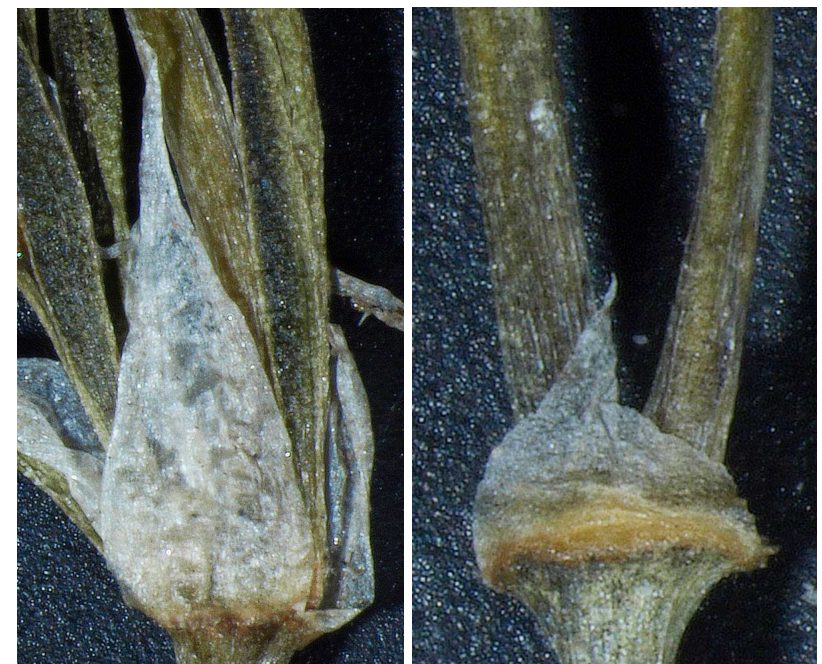

3. ábra A S. rubra és a S. echinosperma pálhalevelei (KúR et al. 2017)

Fig. 3 Bracts of $S$. rubra and S. echinosperma 
A Spergularia echinosperma hazai herbáriumi adatainak felsorolása:

1. BP 644426 S. rubra, Ercsi in salsis arenosis insulis (dátum nélkül) leg.: Tauscher Gyula (CEU: 8879.1); rev.: S. echinosperma 2 pld. (lap tetején) + S. rubra 1 pld. (lap alján), J. Foucaud, 1903.05.01.; rev.: S. echinosperma 2 pld. (lap tetején) + S. rubra 1 pld. (lap alján), Mesterházy A., 2018.01.18.; rev.: S. echinosperma subsp. albensis 2 pld. (lap tetején) + S. rubra 1 pld. (lap alján), P. Kúr, 2018.

2. BP 645454 S. rubra, In arenosis humidis praedii Sinatelep prope oppidum Ercsi 1876.08.03. leg.: Tauscher Gyula (CEU: 8879.1); rev.: S. echinosperma, J. Foucaud, 1903.05.01.; rev.: S. echinosperma, Mesterházy A., 2018.01.18.; rev.: S. echinosperma subsp. albensis, P. Kúr, 2018.

A Magyar Természettudományi Múzeum (BP) Carpato-Pannonicum gyűjteményének S. rubra lapjai közé besorolt példányok között előkerült egy $S$. echinosperma gyűjtés Somorja (Šamorín) mellől, ami ugyan már Szlovákiában, de közvetlenül a magyar határ túloldalán található:

3. BP 51705 S. rubra, Dunánál torlaszokon, Somorja 1868.09.11. leg.: Résely Mihály (CEU: 7969.4); rev.: S. echinosperma, Mesterházy A., 2018.01.18.; rev.: S. echinosperma subsp. albensis, P. Kúr, 2018.

Ez az adat korábban Szlovákiából nem volt ismert, legközelebb a növény Pozsony (Bratislava) térségéből került elő (DvoŘÁK 1979). A faj kárpát-medencei adatai az 1800 -as évek közepéből és az 1900-as évek elejéről származnak, a későbbi gyűjtések között nem sikerült egyetlen példányt sem azonosítani. Ercsi környéke az 1900-as években jelentős átalakuláson ment keresztül, a település térsége ma már döntően szántóterület. Bár kis kiterjedésben ma is vannak szikesedő gyepek, ezeken a fajt nem sikerült megtalálni. Ugyancsak eredménytelenül kerestük a növényt a Duna szigetközi szakaszán lévő iszappadokon. A S. echinosperma-t így hazánk területéről kipusztultnak (EX) kell tartanunk, bár nem kizárt, hogy a faj még lappanghat nálunk és a közeljövőben előkerülhet. Erre a legnagyobb esély az Öreg-Duna szigetközi szakaszán, valamint a Nagy-Alföld természetes mocsaraiban van. A faj Ercsi melletti élőhelye (nyílt szikes folt) hasonló lehetett a Kazahsztánból újonnan kimutatott előforduláséhoz (EFREMOV et al. 2019), ami utal arra, hogy egy mérsékelten sótűrő növényről van szó, annak ellenére, hogy Európa más részein főleg édesvízű iszapnövényzetben találták.

A fajt a legutóbb módosított határozókulcsba (ScHMIDT et al. 2018) a következőképp illesztettük be:

1a A virág 8-12 mm Ø. A tok (5-)6-8(-10) mm hosszú, kb. 2× hosszabb a csészénél. A magok világosbarnák, (75-)96-100\%-uk széles hártyás szegélyű. - A levél húsos, csúcsa nem szálkás. A szirom 2,5-5 mm hosszú, halvány rózsaszínű, töve fehér. Porzó (7-)10. T: 5$20(-40) \mathrm{cm}$. He. VII-X. Agyagos-szikes pionír társulások, az utak sózásával terjed. DDt (Balaton-part) ritka, NA szikes területein szórv., KisA ritka, másutt (pl. NyDt) adv. [S. maritima (All.) Chiov.].

$$
\text { S. media (L.) C. Presl - Szárnyasmagvú budavirág }
$$

1b A virág 6-8 mm $\emptyset$. A tok 2,5-6 mm hosszú, alig hosszabb a csészénél. A magvak nagy része v. az összes mag hártyás szegély nélküli ....

2

2a A növény élénkzöld. A levelek húsosak, csúcsuk nem szálkás, t-k kopasz. A magok világosbarnák, széles hártyás szegély nélküliek v. kisebb részük hártyás szegélyű. A pálhák egy része a tövénél összenőtt, 1-2× olyan hosszúak mint szélesek, alig fényesek, csúcsuk tompa. A szirom 2-3 mm hosszú, sötét rózsaszínű, töve élesen elválva fehér. Porzó (2-)5(-9). A tok kevéssel hosszabb, mint a csésze. T: 5-20 cm. Th-HT. V-X. Agyagos-szikes pionír 
társulások, az utak sózásával terjedőben. K (szélei), DDt (Balaton-part), KisA ritka, NA szikes területein szórv., másutt (főként Dt) adv. [S. salina J. Presl et C. Presl].

S. marina (L.) Bess. - Sziki budavirág

2b A növény mirigyszőröktől szürkészöld. A levelek nem húsosak, csúcsuk szálkás, ált. dúsan mirigyszőrös. Pálhák szabadok. A magok széles hártyás szegély nélküliek 3

3a A magok világosbarnák, ritkán sötétbarnák, felszínük elszórtan bibircses. A középső és alsó levelek pálhái 2-3× olyan hosszúak mint szélesek, fényesek, csúcsuk kihegyezett. A szirom 1,5-4 mm hosszú, élénk rózsaszínű, töve alig halványabb. Porzó 5-10. T: 5-30 cm. Th-HT. V-IX. Mészkerülő. Szántók, nedves gyomtársulások, iszaptársulások. M. e. t. szórv.

S. rubra (L.) J. Presl et C. Presl - Piros budavirág

3b A magok sötétbarnák, felszínük sűrűn bibircses. A középső és alsó levelek pálhái 0,7-1,2× olyan hosszúak mint szélesek, fényesek, csúcsuk kihegyezett. A szirom 2,1-3,2 mm hoszszú, élénk rózsaszínű, töve alig halványabb. Porzó 5-8. T: 3-8 cm. Th. VI-X. Iszapnövényzetben. A (Duna-völgy: Ercsi) †.

S. echinosperma (Čelak.) Asch. et Graebn. subsp. albensis Kúr - Bibircsesmagvú budavirág

\section{Köszönetnyilvánítás}

Köszönet illeti Barina Zoltánt (MTM Növénytár, Budapest) aki a herbáriumi adatgyüjtésben volt a segítségünkre.

\section{Irodalomjegyzék}

AnON. (2009): Spergularia. - In: KiRÁLY G. (szerk.) (2009): Új magyar füvészkönyv. Magyarország hajtásos növényei. Határozókulcsok. ANP Igazgatóság, Jósvafő, pp. 541-142.

Ascherson P. \& GRAebner P. (1893): Beiträge zur Kenntniss der norddeutschen Flora. - Berichte der Deutschen Botanischen Gesellschaft 11: 516-530.

Bartha D., Király G., Schmidt D., Tiborcz V., Barina Z., Csiky J., Jakab G., LeSku B., Schmotzer A., Vidéki R., VojtKó A. \& Zólyomi Sz. (szerk.) (2015): Magyarország edényes növényfajainak elterjedési atlasza. Nyugat-magyarországi Egyetem Kiadó, Sopron, 330 pp.

BitTRICH V. (1993): Caryophyllaceae. - In: KUBITZKI K. et al. (eds), The families and genera of vascular plants 2., Berlin, Springer, pp. 206-236.

ČElAKovskÝ L. (1881): Prodromus der Flora von Böhmen. Vol. 4. - Archiv der Naturw. Landesdurchforschung von Böhmen, IV. Band. Nro. 3. (Botanische Abtheilung.), pp. 693-955.

DvoŘÁK F. (1989): Chromosome counts and chromosome morphology of some selected species. Scripta Facultatis Scientiarum Naturalium Universitatis Purkynianae Brunensis 19: 301-322.

DvořÁk F. (1990): Spergularia - kuřinka. - In: HejnÝ S. \& Slavík B. (eds), Květena České republiky 2. Praha, Academia, pp. 81-86.

DvoŘÁK F. (1979): Některé výsledky studia druhu Spergularia echinosperma Čelak. - Zprávy Československé Botanické Společnosti 14: 109-116.

EBEL L.A. (2012): Abstract of the flora of the northwestern part of the Altai-Sayan province [Конспект флоры северо-западной части Алтае-Саянской провинции]. - Kemerovo, KREOO "Irbis", 564 pp.

EFremov A.N., GAZAiX A. \& Mesterházy A. (2019): Floristic finds of aquatic and shallow waters vascular plants in the north of the Republic of Kazakhstan (in Russian). - Bulletin of Moscow Society of Naturalist. Biological series 124(6): 68-70.

Eliáš P. Jun., DítĚ D., KLIMENT J., HRivnÁK R. \& FERÁKovÁ V. (2014): Red list of ferns and flowering plants of Slovakia, 5th edition (October 2014). - Biologia 70(2): 218-228.

FRIEDRICH H.C. (1979): Familie Caryophyllaceae. - In: RECHINGER K.H. (ed.), Gustav Hegi, Illustrierte Flora von Mitteleuropa 3/2. Angiospermae, Dicotyledones 1. Phytolaccaceae, Amaranthaceae, 
Chenopodiaceae, Illecebraceae, Caryophyllaceae, Portulacaceae. 2nd ed. Berlin \& Hamburg, Paul Parey, pp. 763-1182.

GRULICH V. (2012): Red List of vascular plants of the Czech Republic: 3rd edition. - Preslia 84: 631-645.

HARTMAN R.L. \& RABELER R.K. (2005): Spergularia. - In: Flora of North America Editorial Committee (eds), Flora of North America north of Mexico 5/2. New York \& Oxford: Oxford University Press, pp. $16-23$.

JAGE H. (1974): Vorarbeiten zu einer Flora der Dübener Heide und ihrer näheren Umgebung. Verhandlungen des Botanischen Vereins für die Provinz Brandenburg 109-111: 3-55.

KÚR P., AMARELL U., JAGE H. \& ŠTECH M. (2017): Taxonomy and evolutionary diversification of the Central European endemic Spergularia echinosperma (Caryophyllaceae). - Phytotaxa 305: 149-164.

Kúr P., KoŠnAR J., KouteckÝ P., Tremetsberger K. \& ŠTECh M. (2016): Origin of Spergularia $\times$ kurkae, a hybrid between the rare endemic S. echinosperma and its widespread congener S. rubra. - Preslia 88: 391-407.

KÚR P., PACHSCHWÖLL C. \& ŠTECH M. (2018): Notes on the distribution of Spergularia echinosperma and the newly recognized species $S$. kurkae in Austria. - Neilreichia 9: 269-282.

KÚR P., ŠTECH M., KoutecKÝ P. \& TRÁVNíčEK P. (2012): Morphological and cytological variation in Spergularia echinosperma and S. rubra, and notes on potential hybridization of these two species. Preslia 84: 905-924.

Mierwald U. \& Romahn K. (2006): Die Farn- und Blütenpflanzen Schleswig-Holsteins. Rote Liste 1. Landesamt für Natur und Umwelt Schleswig-Holstein, Flintbek Band, 122 pp.

Monnier P. \& Ratter J.A. (1993): Spergularia (Pers.) J. \& C. Presl - In: Tutin T.G. et al. (eds), Flora Europaea 1., 2nd ed. Cambridge (U.K.), University Press, pp. 186-188.

Monnier P. (1968): Synopsis du genre Spergularia (Pers.) Presl au Maroc. - Naturalia Monspeliensia Série Botanique 19: 87-113.

Niklfeld H. \& SchratT-Ehrendorfer L. (1999): Rote Liste gefährdeter Farn- und Blütenpflanzen (Pteridophyta und Spermatophyta) Österreichs, 2. Fassung. - In: NikLfeld H. (ed.), Rote Listen gefährdeter Pflanzen Österreichs. Grüne Reihe Bundesministerium Umwelt, Jugend und Familie. Graz, Austria medien service, pp. 33-151.

Poppendieck H.-H., Bertram H., Brandt I., Kreft K.-A., Kurz H., Onnasch A., Preisinger H., Ringenberg J., Prodzinski J. \& Wiedemann D. (2010): Rote Liste und Florenliste der Gefäßpflanzen von Hamburg. Hamburg, Freie und Hansestadt Hamburg, Behörde für Stadtentwicklung und Umwelt, Abteilung Naturschutz, $54 \mathrm{pp}$.

SCHMidT D., HASZonits Gy. \& KoRDA M. (2018): Sótűrő budavirágfajok terjedése a Dunántúl útjain. Kitaibelia 23(2): 141-150.

Schulz D. (2013): Rote Liste und Artenliste Sachsens. Farn- und Samenpflanzen. - Dresden, Sächsisches Landesamt für Umwelt, Landwirtschaft und Geologie, $304 \mathrm{pp}$.

Taran G.S., Tyurin V.N. \& DyaChenko A.P. (2018): About two associations of the Ob River alluvial vegetation, Tomsk Region. (in Russian) - Phytodiversity of Eastern Europe 12(2): 153-169.

VoigtLÄNDER U. \& HENKER H. (2005): Rote Liste der gefährdeten Höheren Pflanzen MecklenburgVorpommerns. - Schwerin, Umweltministerium Mecklenburg-Vorpommern, $59 \mathrm{pp}$.

Beérkezett / received: 2021. 01.19. • Elfogadva / accepted: 2021. 02. 28. 